Назаров В. Д. Свержение ордынского ига на Руси. М., 1983.

Назаров В. Д. Рассказ Вологодско-Пермской летописи о Стоянии на Угре // Великое Стояние на реке Угре и формирование Российского џентрализованного государства: локальные и глобальные контексты. Калуга, 2017. C. $251-269$.

Новикова О. А. Лихачевский «летописеџ от 72-х язык»: к истории создания и бытования // Летописи и хроники. Новые исследования. 2009-2010. М., СПб., 2010. С. 237-272.

Новикова О. Л. «Сокрашенный свод» в 70-90-х гг. XV века и его Соловешкий вид // Летописи и хроники. Новые исследования. 2013-2014. М., СПб., 2015. С. 162-234.

Панченко ФD. В. Международная научная конференџия «Славянская библия в эпоху раннего книгопечатания» // Русская литература. 2017. № 4. С. 264-271.

Петров В. А. Географические справочники XVII в. // ИА. М.; Л., 1950. [Т.] V. С. 237-272.

Стрельников С. В. Землевладение в Ростовском крае. М.; СПб., 2009.

Vladislav D. Nazarov

Institute of World History of the Russian Academy of Sciences, Moscow, Russia

\title{
REVISITING TWO IMPORTANT EVENTS OF AUTUMN 1480
}

The most important result of the successful warfire between arising unified Russian state and the army of the Great Horde's Khan Akhmat in summer - autumn of 1480 was the liquidation of political and tributary dependance of Rus' from the Horde. The events of late September - early November became the climax of this half a year struggle. We should consider among them the facts relating to Ivan III's stay in Moscow in late September - early October. The accounts of the chronicles of the late $15^{\text {th }}-$ early $16^{\text {th }}$ century that stands very close to these events as well as the documents of that time permit to give an original interpretation of two events from the deeds of the Grand Prince of Moscow in his capital during this period.

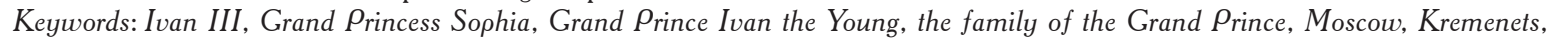
Dmitrov, Beloozero, coffers, Moscow chronicles and chroniclers of the late $15^{\text {th }}$ century

\section{УДК 94(438).03; 94(47).04 >(470.332) ББК 63.3 (0)4 DOI 10.25986/IRI.2019.75.1.0023 \\ С. В. Полехов}

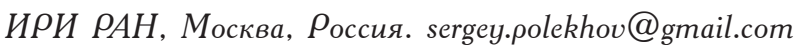

\section{ПРИВИЛЕЙ АЛЕКСАНДРА ЯГЕЛЛОНА СМОЛЕНСКОЙ ЗЕМЛЕ 1505 г. ${ }^{1}$}

Текст привилея короля польского и великого князя литовского Александра Ягеллона публикуется по подлиннику, хранящемуся в Главном архиве древних актов в Варшаве, согласно современным принџипам издания кириллических документов Великого княжества Литовского.

Ключевые слова: Великое княжество Аитовское, Александр Ягеллон, областные привилеи, Смоленская земля

Ниже публикуется текст привилея короля польского и великого князя литовского Александра Ягеллона Смоленской земле от 1 марта 1505 г. Новая публикаџия по подлиннику оказалась необходимой для спеџиального исследования истории складывания текста этого документа, вобравшего в себя нормы привилеев, выданных великими князьями литовскими начиная с 1447 г. [Полехов]. Привилей 1505 г. несколько раз публиковался по списку в 5-й книге записей Литовской метрики, содержашему џелый ряд искажений оригинального текста; при этом к подлиннику его публикаторы не обрашались. Достаточно сказать, что его не указывает даже Эгидиюс Банёнис, чрезвычайно тџательно отмечавший подлинники, списки, публикаџии и упоминания документов подготовленной им второй части 5-й книги записей; в недавней публикаџии В. С. Позднякова привилей напечатан по тому же списку со всеми присущими ему искажениями оригинального текста. Единственная же публикаџия, выполненная по подлиннику, вышла в составе малоизвестного польского издания конџа XIX в. и уже не соответствует потребностям современной науки. В тексте, набранном стилизованным шрифтом, нередко путаются сходные по написанию буквы «б», «В» и «К», а также «и» и «Н»; не всегда удачна разбивка на слова (так, частиџа «ж» печатается слитно с предшествуюшим словом), иногда она меняет смысл текста (в ст. 1.5 вместо «не надобъ» напечатано «ие на добъ»); имеются неточности в передаче текста, в особенности при внесении выносных букв в строку: вместо «такеж» почти во всех случаях напечатано «также», в ст. 4 вместо «ино, деи»- «иноди», а вместо «пос8л»- «посл8». Особенные трудности публикатору доставил термин «школ(ь)ничие», вместо которого дважды было напечатано «школичне» (впрочем, последнюю ошибку удалось исправить в списке опечаток ${ }^{2}$ ). Текст привилея не был разбит ни на статьи, ни на абзаџы.

\footnotetext{
1 Работа подготовлена в период постдокторантской стажировки в Вильнюсском университете (проект «Формирование системы управления русскими землями Великого княжества Литовского в XIV - XV вв.»), финансировавшейся по проекту С труктурных фондов Европейского союза «Осушествление постдокторантских стажировок (постдок) в Литве» в 2013-2015 г. Благодарю за оказанную помошь Г. М. Брегера (Минск), А. И. Грушу (Минск), К. Ю. Ерусалимского (Москва), А. В. Казакова (Минск) и Т. Ящолта (Варшава).

2 Zbiór dokumentów znajdujących się w Bibliotece hr. Przezdzieckich w Warszawie / Wyd. A. Chmiel. Kraków, 1890. S. 161.
} 


\section{С. В. Полехов}

Для настоящей работы текст подготовлен в џелом в соответствии с современными принџипами публикаџии кириллических документов Великого княжества Литовского, разработанными А. И. Грушей [Метадычныя рэкамендаџыі] и реализованными в недавнем издании полоџких грамот ${ }^{3}$. При этом, однако, ниже не воспроизводятся ни «квадраты», образованные линиями сгибов, ни точки, служившие при чтении документа пограничными сигналами между словами и группами слов: они лишь учитываются при характеристике расположения дорсальных пометок и разбивке текста привилея на предложения, абзаџы и статьи, произведенной автором этих строк. В примечаниях подведены важнейшие смысловые разночтения со списком привилея в 5-й книге записей Литовской метрики, а также отмечены места, которые в подлиннике читаются лишь в ультрафиолетовом освеџении или не читаются вовсе и реконструируются по списку в Метрике (в тексте они заключены в квадратные скобки).

Спеџиального внимания заслуживает архивная судьба подлинника, оказавшегося к конџу XIX в. в собрании Пшездзеџких. К ним он, судя по всему, перешел от Тизенгаузов, получивших его вместе с другими материалами княжеского рода Крошинских, один из представителей которого, Тимофей Ф илиппович Крошинский, был последним смоленским казначеем ${ }^{4}$ [Tęgowski, s. 42]. Это добавляет важный штрих в картину бытования областных привилеев в Великом княжестве Литовском [Якубовский, с. 245-246].

1505 г. марта 1. Берестье. - Привилей короля польского

и великого князя литовского Александра Ягеллона Смоленской земле

AGAD. Zbiór dokumentów pergaminowych. $\mathrm{Nr} 5874$. Пергамен (светло-желтый, с многочисленными бурыми пятнами от влаги), $59 \times 66-65,5$. Подлинник $-A$.

Вдоль нижнего края загиб высотой 8,5-6,8 см, левая часть загиба обрезана с закруглением. Поля: верхнее 4,5-4,7 см; левое - 7,3 см; правое - 3 см. В нижней части листа под текстом и в закладке прорезаны по два треугольных отверстия, сквозь которые продет витой инурок из белых и черных нитей, сходящийся к нижнему краю. Печать не сохранилась.

Пометки. У левого верхнего угла загиба красным карандашом: 44 (XIX в.). На обороте в левом верхнем углу, простым карандашом: Nr. 5874 (ХХ в.). В верхнем среднем квадрате у его правого края снизу вверх по вертикали простым карандашом: 5874 (XX в.). В левом среднем квадрате в его левом нижнем углу в перевернутом виде бумажная наклейка с иифрами в синей рамке: XXVII.|I. (XIX-XX в.). В правом среднем квадрате ближе к левому краю в перевернутом виде красными чернилами: $\mathrm{Hr}$ St.|5. (XIX-XX в.). Правее в перевернутом виде синим карандашом: $\mathrm{S} \mid 1501$ (XIX-XX в.). В левом нижнем квадрате у его верхнего края сильно выцветшими коричневыми чернилами: Roku 1489 [...]. Ниже в том же квадрате светло-коричневыми чернилами: Prziwilei Smolnianom na niektore wolnosci $(X V I-X V I I I$ в.). В том же квадрате ближе к нижнему краю темно-коричневыми чернилами: Mnie niepotrzebny, | chować go [...]. В среднем нижнем квадрате у его верхнего края темно-коричневыми чернилами: Przywiley na wolnosci miastu Smolenskiemu | od krola Alexandra $1501 \mid$ [ ...] nie należący do spraw Jesionowskiech (XVI-XVIII в.). В правом нижнем квадрате у его верхнего края коричневыми чернилами: Przywiley od Nayiasnieyszego |Alexandra K. P. miastu Smolensko|wi dany 1501 roku (XVI-XVIII в.).

Списки: В) РГАДА. Ф. 389. Оп. 1. Ед. хр. 5. Л. 318-321 (по Б - списку с $A$; конещ XVI - начало XVII в.); $\Gamma$ ) AGAD. Metryka Litewska - transkrypcje. Ks. 192. S. 537-540 (по В; втор. пол. XVIII в.); Д) РГБ. Ф. 256. № 75. № 5. $ᄉ$. 45-56 (по $Г$; XIX в.).

Осн. публ.: а) Сборник Муханова. М., 1836. (2-е изд. СПб., 1866.) № 85. С. 135-139 (по Д); б) Акты, относяшиеся к истории Западной России. СПб., 1846. Т. 1. № 213. С. 359-363 (по В); в) Никитин П. История города Смоленска. М., 1848. Прил. № X. XXI-XXVII (по б); г) Любавский М. К. Очерк истории Литовско-Русского государства до Люблинской унии включительно. СПб., 1915. Прил. 2. С. 346-349 (по B); д) Zbiór dokumentów znajdujących się w Bibliotece hr. Przezdzieckich w Warszawie / Wyd. A. Chmiel. Kraków, 1890. № 27. S. 52-59 (по A); е) Lietuvos Metrika. Knyga Nr. 5 (1427-1506). Užrašymų knyga 5 / Par. E. Banionis. Vilnius, 1993. № 157. P. 272-275 (по B); ж) Lietuvos Metrika. Knyga Nr. 5 (1427-1506). Užrašymų knyga 5 / Par. A. Baliulis, A. Dubonis, D. Antanavičius. Vilnius, 2012. № 561. P. 376-379 (по B); з) Пазднякой В. C. Помнікі права Беларусі XIV-XVI ст.: абласныя прівілеі. Крыніџазнаўчы дапаможнік. Мінск, 2018. С. 213_218 (по B).

Пересказ содержания: Danitowicz I. Skarbiec diplomatów papiezkich, cesarskich, krolewskich, książęcych. Wilno, 1862. T. 2. № 2164. S. 270-272 (по $Г$ ).

Во има Б(о)жье, аминь ${ }^{5}$.

Высоких паншв подданыє г(о)с(по)д(а)рьства рАдностью справ посполитая рђчь и знамънитыє ч(ес)ти доступають. Про то к8 въчнои тоє то рБчи памати, мы, $\mid$ Александрь ${ }^{6}$, кшрол(ь) польскии, великии кн(А) зь литовскии, р8скии, кн(А)жа прускоє, жомоитьскии и иных, чиним знамЂнито сим нашим листшм, хто на него посмотрить або чт8чи єго вслышит, н(и)нЊшним и потшм ${ }^{7} \mid$ б8дучим, ком8 б8деть потреб того въдати.

Били нам чолшм вл(а)д(ы)ка смоленскии Ишсиө, и школ(ь)ничиє ${ }^{8}$, и вси кн(А)зи, паншвъ, и боярђ и мъџане, и чорныє люди, и все поспол (ь)ство мъста, земли Смоленьскоє, | и клали перед нами привилеи маєстат шастноє памАти

3 Полоцкие грамоты XIII - начала XVI века / Отв. ред. А. ‥ Хорошкевич; Подг. С. В. Полехов, В. А. Воронин, А. И. Груша, А. А. Жлутко, Е. Р. Сквайрс, А. Г. Тюльпин. М., 2015. Т. 1-2.

${ }_{4}$ Так, в архиве Тизенгаузов сохранился привилей Сигизмунда Старого Т. ФD. Крошинскому на смоленские имения, выданный 15 сентября 1508 г. взамен документов, захваченных в имении его брата Ивана Михаилом Глинским (AGAD. Dok. perg. Nr 5881; датируется по индикту и итинерарию Сигизмунда).

5 Написано увеличенным почерком; иничиал высотой 15 строк

${ }^{6}$ Далее в В: Божью милостью

7 напотом $B$

${ }^{8}$ Далее в В: смоленские 
wту и оубачивши их к8 егш м(и)л(о)сти и теж|к8 предкшм нашим вьрную а справедлив8ю служб8, иж предковь их и шни завжды оу въре своєи заховалиса и николи часу пригоды на них и налшги шт размаитых неприятелеи Великого кн(А)зьства Литов |скшго завжды нештступни были, а тому г(о)с(по)д(а)рю, которыи сьдел на Вил(ь)ни а на Троџох, всАкою вЂрНою Послугою служили и против8 єго неприятелеИ руку свою Подносили аж до горла своєго, $\omega m($ е) наш, Доброє ПамАти кшрол(ь) Казими $\rho$, за тую выше Писану вђрность их, хотАчи им з особливоє своєє ласки досыть вчинити ${ }^{9}$, дал им привилеи свои. И после того в кул(ь)ку льтех єго м(и)л(о)сть, вже паном|коруншваным б8дучи, со всими прелаты и паны радами своими их смотрел с паншм Миколаем Радивиловичом в тот часъ, как шт

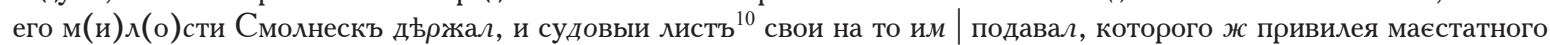
и листов судовых єго м(и)л(о)сти вси члонки выбравши, казали єсмо вписати в сесь нашь листъ. И так са в собъ мають тым шбычаєм.

[1.1.] Наипервъи, што ж нам $\mid x \rho($ е)стьянства грђческого закшн8 не рушити, налшги им на их въру не чинити, а въ џ(е)рковныи земли и в воды не вст8патиса.

[1.2.] Такеж и в монастыри и в отмершины не вступатися.

[1.3.] А по см(е)рти мужни жоны $\mid$ з дом8 не двигнути и по неволи замуж их не давати.

[1.4.] А хто, штхода того свъта, ком8 прикажеть свои статок, того не рушити.

[1.5.] Такеж и в татиноє берема не вст8[патися нам а] ${ }^{11}$ ни намъстник8 смоленском8, нежли шПАт(ь) $\mid$ штдати том8, в кого што вкрадено.

[1.6.] Теж ${ }^{12}$ тамга горожаншм ${ }^{12}$ смол(ь)наном не надобъ, нежли на гостех тамга брати.

[1.7.] А корчмы в городе Смоленьск8 не держати.

[1.8.] А такеж в роки выдавки, што шдин выдастьса, а другии не вы|дастьса, тут вины нет. А коли шба выдадутсА, ино, с8дом дошод, на виноватом вина взАти. А деџкованьє по старом8.

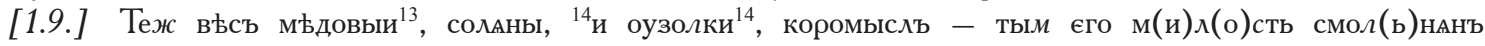
жа|лшвал.

[1.10.] А сто рублев, што з города даивали на год, то єго м(и)л(о)сть им навъки штпвстил.

А што төеричи, мъстичи смоленьскии, двадџать рублев грошеи даивали, то єго м(и)л(о)сть такеж им штпвстил.

[1.11.] А бояром $\mid$ смоленьским в закладни людеи своих не казал єго м(и)л(о)сть приимати.

[1.12.] А подвод горожаншм не велел давати, казал єго м(и)л(о)сть подводы держати з волостеи на свои потребы, а к приєзд8 своєм8 и горожаншм подводы $\mid$ велел єго м(и)л(о)сть давати по тшм8, как и при великом кн(А)зи Витовте даивали.

[1.13.] А што волости держивали боярђ смоленскиє, то таки им держати по старшм8, как пожал8ем котшрого боярина смоленского кото|рою волшстью. А што Швитригаилш штвърнул был волшсти шт Смоленска, тыє волости заса єго м(и)л(о)сть привернул к Смоленск8. И што был великии ${ }^{15}$ кн(А) зь ${ }^{16}$ Витовтъ штвърну $\Omega^{17}$ бы $л$ ко Мстиславлю Смоленскоє волости | молоховскиє люди, и тыє люди шпАть єго м(и)л(о)сть привърнул к Молохвђ по старом8. А тых волшстеи смоленских никшм8 не держати, нежли бояром смоленским же.

[1.14.] Теж и то єго м(и)л(о)сть выписал им в привилеи своєм: єстли бы смол(ь)НАне $x$ wm соли и $ш т$ воск8, и єго м(и)л(о)сть такеж смолнАншм велел брати на Полочане $x$ шт соли и шт воск8; а єстли бы Полочане на смол(ь)нанеХ не брали, ино и смол(ь)наном на полочане $х$ не брати.

[1.15.] А которое | право дал єго м(и)л(о)сть кн(А)зем и паншм, бояршм литовским, тоє жь право дал єго м(и)л(о)сть кн(А)зем, паншм, бояршм смоленьским.

Далеи єго м(и)л(о)сть в том привилеи своєм выписал и иныє чльнкии к8 полепшенью земли Смоленьскоє. |

[2.1.] А што єго м(и)л(о)сть смотрел их с паны радою своєю ш том, иж пан Миколаи Радивиловичь, воєвода виленьскии, канџльрь ${ }^{18}$, как wm єго м(и)л(о)сти Смолнескъ держал, хотел им новины оуводити тыє: коли 3 города Смоленьска | еждивал по дворшм смоленьским, а любо в ловы, тогды в них подводы биривал з мъста под себъ и под свои рђчи, а школ(ь)[ничи]е смоленскиє ${ }^{19}$, и намъстник, и слуги [пана] Миколаєвы ${ }^{20}$ такеж в них подводы з мъста би|ривали; а коли на Глвшиџи пан Миколаи мешкивал, ино сл8ги много в них з мъста чолнов $8^{21} 3$ люд(ь)ми бирали под єго речи, которыє коли до него к Глушиџи проваживали; такеж, коли сам мешкивал в городь

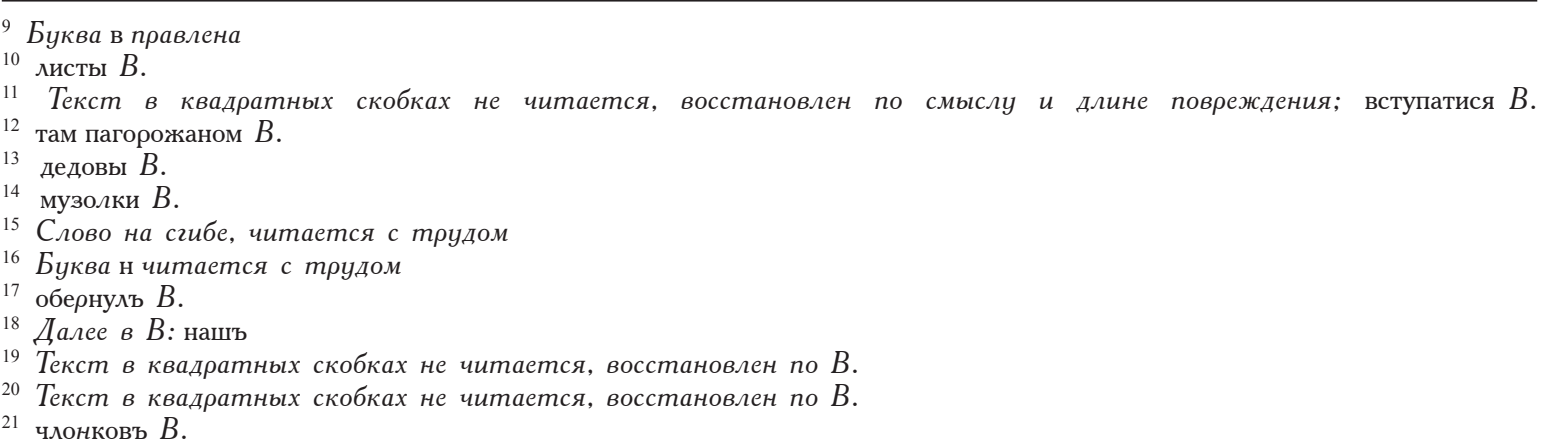




\section{С. В. Полехов}

| в Смоленск8, тогды велел им сторожи давати на свои дво $о$ со всего мЂста, чого ж здавна за великого кн(А) ЗА Витовта, и за Жикгимонта, и за штџа нашого, королА его м(и)л(о)сти, николи не бывало, нежли тол(ь)ко даивано по два $\mid$ сторожи до скарб8 намъстникшв смоленских в тот час, коли шни з города зъєжчали, и то с тАглых людеи, которые здавна т8ю 22 служб8 служивали; такеж сл8ги пана Миколаєвы, и вл(а)д(ы)чни, и школ(ь)ничих слуги деџкован(ь)я почали были много на них брати, не по том8, как перед тым бирано, wт рублА по чотыри гроши, а $w m$ полтины по два гроши, а на милю деџкован(ь)я по грош8, а коли на справу ${ }^{23}$ пошлютсА, ино по два гроши на милю на них | бирано.

[2.2.] А коли которыи ч(е)л(о)в(е)къ впадет оу вин8, а любо на котором ч(е)л(о)в(е)џе заплату ${ }^{24}$ прис8дат ком8 и в ынших в малых делех, сл8ги пана Миколаєвы, и вл(а)д(ы)чни, и школ(ь)ничих слуги их в доводню сажають, а на пор8ки не дают. | Котороє ж дело єго м(и)л(о)сть на тои мере поставил: коли кого вина шбоидет, а любо которыи ч(е)л(о)в(е)къ ком8 будеть чим виноват, и теж до права черес пор8к8 тых всих не казал єго м(и)л(о)сть в доводню сажати в таковых малых дълех, | а велел их за пор8к8 давати, кром своєго великого дъла, в котором же не пригодитса на пор8к8 давати.

[2.3.] Такеж рАдничии пана Миколаєв бирал взвъстк8 в гостеи, в к8пџов, которыє приєжчают со Мстиславла, с Кричова и з ыншых | городов, чого ж перед тым не бывалш, а против того на смол(ь)нанеХ во Мстиславли и в Кричове и в ыны смоленских на мстиславџох и на кричовџох и на их купџов наших городов| и мъстъ взвъстки не бирали, нежли бирали взвђстк8 на москвичох, на төеричох и на иных к8пџов чужоземџох.

[2.4.] Такеж и сокол(ь)ничие ${ }^{25}$ смоленскиє и намъстникшв смоленских ${ }^{26}$ новины оувъли были ${ }^{26}$ на тых к8пџох, которые з ВАз(ь)мы, | и з Дорогоб8жа, и зо Мстиславля, и съ сел привозАт к город8 маса Продавати џелыми стАги, бирали съ стАг४ по пол8грош $8^{27}$, а того здавна не бывало, нежли с тых резникшв, которыє в мъсте живут и маса Продают, тот доход сокол(ь)ничие | бирали.

[2.5.] Теж и ловчии пана Миколаев новину им оувел был: с8дил их и рАдил по всем8 мъст8 и деџкии свои на них давал, чого ж здавна не был[о, н]ежли ${ }^{28}$ намъстник смоленскии с окол(ь)ничими и 3 ыншими врАдники | суживал их на нашом дворђ, а ловчии при том же бывали и доходџов своих врочных смотривали.

[2.6.] Такеж и т8ю новин8 пан Миколаи оувњ $л$ был им: велел им со всего мъста люди выгонати ${ }^{29} п р 8 д о в$ сыпати на Єсен8ю29, а зда|вна того мъщане не делывали, нежли тАглыє люди пруды сыпывали.

И $w m\left(\right.$ е)џь нашь, кшрол(ь) єго м(и)л(о)сть, с паны радою своєю, довъдавшиса того достаточне ${ }^{30} w$ т окол(ь)ничи $x^{30}$, и $ш т$ кн(А)зеи ${ }^{31}$ и боя $\rho$ земли Смоленскоє, иж тыє $\mid$ пошлины всим им ново оувђдены, и заса тыє вси новины выше писаныє єго м(и)л(о)сть им штложил, а вчинил все по старшм8, как перед тым бывало.

Такеж клали перед нами третии листъ штуа нашого, королА $\mid$ єго м(и)л(о)сти, которыи єго м(и)л(о)сть писал до пана Миколая ж Радивиловича ш кривдах и ш новинах, которыє мъсту Смоленском8 часу ${ }^{32} є г о$ держанья деялис ${ }^{33}$.

[3.1.] Напервеи, што са тычет ябедников, которыє, ходАчи по $\mid$ мЂст8, людеи соромотАт и боєм кльплют,

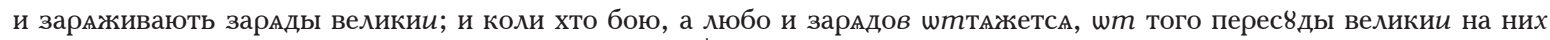
намъстник и школ(ь)ничие в оныи час биривали. |Ино в том своєм листе єго м(и)л(о)сть писал: которыє бы ябедники людеи дармо клепали боєм, а любо зарАды великиє закладали, а пришодши на суд, того сА не доиџут, ни бою, ни зарАдов, абы тых ябедников $\mid$ винами карано подль их заслуги, которыи чого ${ }^{34}$ б8деть заслужил.

[3.2.] Теж в том же листу єго м(и)л(о)сти выписано, абы конюшии брали с конского и з животинного стада з мъстьского к8ниџ8 по дванадџати ${ }^{35}$ грошеи | на льто подль давного шбычая, как перед тым бывало, за великого кн(А)за Витовта и за Жикгимонта.

[3.3.] Далеи ${ }^{36}$ в том листе єго м(и)л(о)сти выписано, абы кн(А)зи, и школ(ь)ничиє, и боярь смоленские оу своих льсех, которыє | школо Днепра мают, и в д8бровах своих не боронили им хоромов р8бити и дров сечи подле давного шбычая, как перед тым бывало.

[3.4.] А хто коли помостное завъдаєт на городе, тот бы с тых людеи, которых дел(ь)ниџа сказитса, | а заса єє замостит, по грош8 брал, а чия делниџа мосту бвдет џела, на том бы ничого не брал.

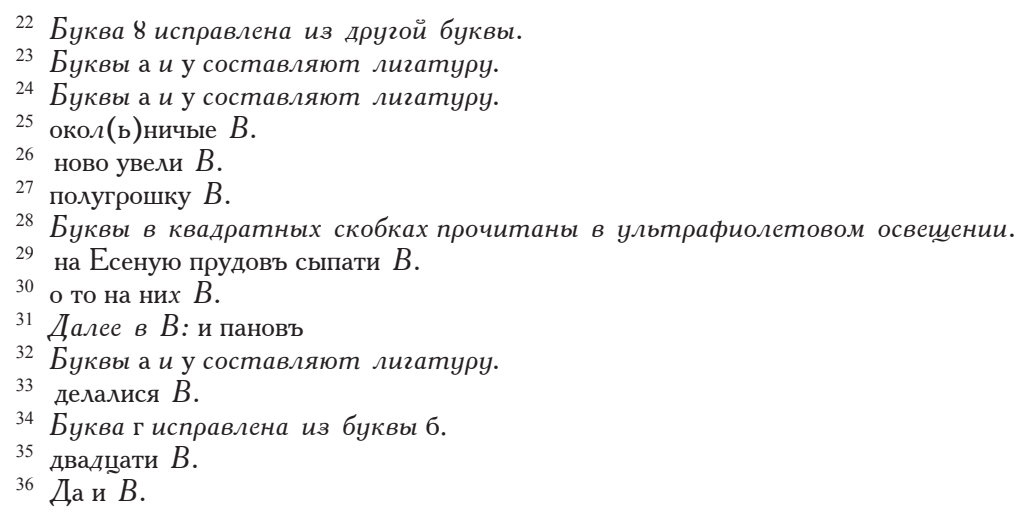


[3.5.] А к8ниџи смирскиє и ${ }^{37}$ свадебные брано бы з них по шести грошеи, а вдов(ь)ю к8ниџ8 по дванадџати грошеи.

[3.6.] А люди кн(А)зьскиє $\mid$ и школ(ь)ничих, и боярскиє, и игуменскиє, которыє в мњсте живут и торгом сА шбыходат, тые бы вси сторожевщину з мъстом платили по силам.

[3.7.] А Хто коли ч(е)л(о)В(е)ка держит в пенАзеХ, тыє бы сами тых людеи своих с8дили и рАдили, | а школ(ь)Ничиє бЫ и иншиє ВрАдники смоленскии в то СА не вст8Пали.

[4.] Такеж которых людеи џ(е)рковных, и кн(А)зьских, и боярских маршалок наш пан Литавор Хрђбтович привђрнул з мЂстом служб8 тагл8ю сл8жити ${ }^{38}$, кром доспешныж ${ }^{39}$ и сл8жебных мЂ|шан, тыє люди вси заса wm мъста штнималиса и не хотели поспол з мьстом нам сл8жити. И коли б8дет потреба

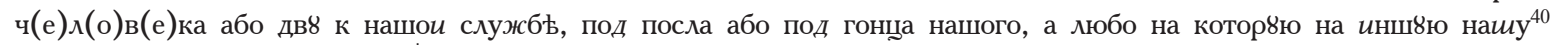
потреб8, ино, деи ${ }^{41}$, подвои|скии з окол(ь)ничих сл8гами все мъсто шбходАт длА шдного ч(е)л(о)в(е)ка

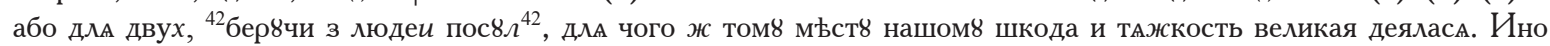
вжо мы писали ш том до пана Ю $\rho($ ь)я Гльбовича, как wm нас $\mid$ Смол(ь)нескъ держал, приказ8ючи єм8, абы тым людем џ(е)рковным и кн(А)зьским 43 и боярским велел поспол з мъстом нам сл8жити по том8, как маршалок наш пан Литаво $\rho$ их к мъст8 в служб8 привърнул. А подвоиских бы старых $x^{44}$, зброднев, выстановил ${ }^{45} \mid$ и шбрал бы на подвоищен(ь)є добрых людеи, а не зброднев, которыє ${ }^{46}$ бы мьшаном любы были. А люд ${ }^{47}$ бы давали на служб8 чергами, и школ(ь)ничих бы слугам ${ }^{48}$ не казали наши $x^{49}$ людеи драпежити. И тот листь наш, которыи єсмо до пана Ю $\rho($ ь)я | писали, тыми разы шни перед нами вказывали и били нам чолшм, абыхмо им то все потвердили нашим листом.

Ино мы, не тол(ь)ко на то маючи взглАд, иж предкове ${ }^{50}$ их были вьрни и оу службах поволни предком нашим, | але вжо и часу ${ }^{51}$ шастного панован(ь)я нашого против8 неприятелем нашим шни досыт(ь) чинили ${ }^{52}$ и нам върне сльжили, яко г(о)с(по)д(а)рю своєм8 штчинном8 и дединном8, - а про то, з ласки ${ }^{53}$ нашоє, длА их върное службы | вси тыє выше писаныє доброволенства подлуг привилея и листу с8дового штџа нашого, королА єго м(и)л(о)сти, и того лист8, которыи єго м(и)л(о)сть до пана Миколая Радивиловича писал ш кривдах и ш новинах | мъста Смоленского, и теж подль нашого листу, которыи єсмо до пана Ю $\rho$ (ь)я Гльбовича писали, маем мы и наши намъстники им и по них б8дучим держати и потвержаєм то им сим нашим листомъ въчно|и непор8шно на въки вькшм.

А при том были паншвђ рада наша: кн(А)зь ${ }^{54}$ Мартин, бискуп жомоитскии, а воєвода виленскии, канџле пан Миколаи Радивилович, воєвода троџкии, маршалшк земскии пан Миколаи | Миколаєвич, пан троџкии, староста жомоитскии пан Станислав Янович, воєвода полшџкии пан Станислав Гльбович, а гетман и маршалок пан Станислав Петрович, а маршалшк дворныи, намъстник|бъльскии, кн(А)зь Михаило Лвович Глинскии, а подчашии, намъстник новгородскии пан Шльбрахтъ Мартинович, и иныє многиє кн(А)зи и пановъ рада наша ${ }^{55}$.

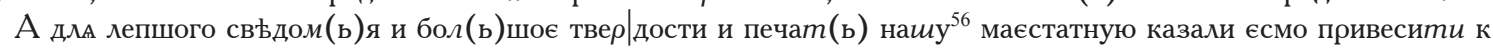
сем8 нашому листу.

Писан и дан в Берестьи, [на $]^{57}$ соимь $^{58}$, въ $^{59} \wedge$ ьm(о) 7013, м(е)с(е)џа марта $[1]^{60}$ ден(ь), индикта шсмого ${ }^{61}$. Ивашкш Сопьжичь, | маршалокъ и писарь ${ }^{62}$.

37 Hem в $B$.

38 тягнути $B$.

39 Так в $A$, следует читать доспешных

40 Буквы а и у составляют лигатуру.

41 Написано над строкой; буквы д и е составляют лигатуру.

42 рекучы, з людеи по грошу поберут $B$.

43 и кн(А) зьским нет в $B$.

44 которых $B$.

45 выставилъ $B$.

${ }^{4}$ Буква є исправлена из буквы 6.

47 люди $B$.

48 слуги $B$.

на них $B$

50 Буква в, вероятно, правлена.

51 Буквы а и у составляют лигатуру.

52 Буква ч правлена.

53 Буква л правлена.

${ }^{54}$ пан $B$.

55 нашы $B$.

56 Буквы а и у составляют лигатуру.

57 Светло-коричневое пятно в А, чернила выщвели; буквы восстановлены по $B$.

58 Буква с правлена.

59 Буква в вписана в букву в.

${ }^{60}$ Светло-коричневое пятно в А, чернила выщвели; буквы восстановлены по $B$.

${ }_{61} 8 \mathrm{~B}$.

62 Подпись на загибе у правого края, выполнена другим, более аккуратным и крупным почерком, чем основной текст привилея. Подпись полностью покрыта светло-коричневым чернильным пятном. 


\title{
Литература
}

Метадычныя рэкамендаџыі па публікаџыі рукапісных актавых кірылічных крыніу у Беларусі (XIII-XVIII стст., перыяд Вялікага княства Літоўскага) / Аўтар-складальнік А. І. Груша. Мінск, 2003.

Полехов С. В. Привилеи великих князей литовских Смоленской земле / / Studia Slavica et Balcanica Petropolitana. 2015. № 1 (17). C. $115-140$.

Якубовский И. В. Земские привилеи Великого княжества Литовского. Ч. 2. Критический разбор текстов областных привилеев // ЖМНП. 1903. № 6. С. 245-303.

Tęgowski J. Kilka uwag o genealogii kniaziów Kroszyńskich do końca XV wieku / / Genealogia. Studia i Materiały Historyczne. Poznań; Wrocław, 2003. T. 15. S. 35-43.

Sergey V. Polekhov

Institute of Russian History of the Russian Academy of Sciences, Moscow, Russia

\section{ALEKSANDER JAGIELLOŃCZYK’S PRIVILEGE FOR THE SMOLENSK LAND (1505)}

The text of the privilege granted by the king of Poland and grand duke of Lithuania Aleksander Jagiellończyk is published from its original preserved in the Central Archives of Historical Records in Warsaw (Archiwum Główne Akt Dawnych) according to the modern principles of editing Ruthenian documents.

Keywords: Aleksander Jagiellończyk, Grand Duchy of Lithuania, land privileges, Smolensk land

УДК 94 (47) ББК 63.3.(2).43 DOI 10.25986/IRI.2019.75.1.0024

\author{
И. Г. Пономарева
}

МГЛУ, Москва, Россия. vasiliy_ii@mail.ru

\section{ОКРУЖЕНИЕ МОСКОВСКОГО ВЕЛИКОГО КНЯЗЯ ВАСИЛИЯ ІІ В НАЧАЛЕ ЕГО ПРАВЛЕНИЯ}

В статье анализируется ситуаџия, сложившаяся при московском великокняжеском дворе после начала самостоятельного правления Василия II. Приводятся известия о соответствуюших мероприятиях. Основной сюжет статьи связан с попыткой проверить выводы А. В. Черепнина. 1. В окружение великого князя вошли новые, молодые люди. 2. Эти изменения и новый политический курс привели к конфликту со старыми боярами.

Ключевые слова: Василий II, московский великокняжеский двор, великое княжество Московское в первой четверти $X V$ в., московские бояре

Историками многократно описан период правления московского великого князя Василия Темного, но при этом не обрашалось внимания на то, как началось его самостоятельное княжение.

Василий II унаследовал престол незадолго до своего 10 -летия и в первые годы управленческие функџии исполнял лишь номинально. Возмужание и переход к самостоятельной политической деятельности были ознаменованы рядом событий.

5 октября 1432 г. состоялось офиџиальное посажение на великокняжеский престол ${ }^{1}$.

Осенью (до или сразу после интронизаџии) Василиї II обручился² ${ }^{2}$ Брак был заключен 8 февраля следуюшего года ${ }^{3}$.

Надо думать, после интронизаџии был заключен ряд договоров ${ }^{4}$.

При оформлении великокняжеских грамот постепенно утверждается практика их удостоверения дьяками подписью «великий князь». Ю. Г. Алексеев посчитал это основным нововведением второго периода феодальной войны, очевидно, подразумевая периодизаџию Л. В. Черепнина, связавшего его со смертью 5 июня 1434 г. удельного князя Юрия Дмитриевича Галиџкого, оспаривавшего у Василия II престол [Алексеев, с. 70; Черепнин, 1960 , c. 763]. На самом деле, первый подобный акт был оформлен в 1432 или 1433 г. ${ }^{5}$

ᄉ. В. Черепнин, комментируя состоявшийся после обручения отъезд из Москвы к Юрию Дмитриевичу самого влиятельного члена великокняжеского двора - боярина Ивана Дмитриевича Всеволожского ${ }^{6}$, предположил, что

${ }^{1}$ ПСРЛ. М., 2007. Т. 27. С. 269, 344; ᄉ., 1982. Т. 37. С. 41, 85; M., 1994. Т. 39. С. 143.

2 ПСРЛ. М., 2001. Т. 6. Вып. 2. Стб. 64-65; М., 2004. Т. 25. С. 250; Т. 27. 269, 344. В древности начало сезонов увязывалось с различными приметами и праздниками, граниџы не были определенными. Самой ранней из дат начала осени было 20 июля, зимы -7 октября (Славянские древности. Этнолингвистический словарь. М., 1999. Т. 2. С. 327; М., 2004. Т. 3. C. 568).

${ }^{3}$ ПСРЛ. Т. 25. С. 250.

4 Были заключены или вероятна возможность заключения следуюших договоров: с Василием Ярославичем Серпуховским и Боровским (ДДГ. № 27. Заключен после смерти летом 1432 г. удельного князя Андрея Дмитриевича, вместо которого в договоре в числе династов фигурируют его сыновья. О датировке акта см. также: [Пресняков, с. 391-392, примеч. 3; Черепнин, 1948, с. 107-108; Зимин, с. 295-296; Кучкин, с. 69]); с Великим Новгородом (ГВНП. № 19; [Пономарева, 2018]); с Иваном Андреевичем Можайским и Михаилом Андреевичем Белозерским и Верейским [Пономарева, 2015]; с рязанским великим князем Иваном Федоровичем 1432 или 1433 г. (ДДГ. С. 448, 463).

5 АСЭИ. М., 1952. Т. І. № 74.

${ }^{6}$ ПСРЛ. Т. 6. Вып. 2. Стб. 64-65; Т. 27. 269, 344. 